\title{
Construction of Competitive Advantage Instrument in Jordanian SME Context Using Structural Equation Modelling
}

\author{
Khaled Alzeaideen ${ }^{1}$ \\ ${ }^{1}$ Faculty Business Administration, Zarqa University, Jordan \\ Correspondence: Khaled Alzeaideen, Faculty Business Administration, Zarqa University, Jordan.
}

Received: August 4, 2019

Accepted: September 5, 2019

Online Published: November 7, 2019

doi:10.5430/ijfr.v11n1p236

URL: https://doi.org/10.5430/ijfr.v11n1p236

\begin{abstract}
Jordanian SMEs are becoming increasingly hard to endure and thrive in the aggressive entrepreneurial world economy due to weak capital structure, poor leadership and weak marketing strategy, as well as other legislative limitations. As a consequence, Jordan faces problems in achieving full advantage from the SME industry as well, making an inadequate contribution to the domestic GDP. Competitive advantage (CA) can, however, perform a crucial part in achieving fast economic development due to sustainability of SMEs and a coherent appropriate input to Jordan's GDP. But the construction of CA is still underdeveloped and ignores a unifying hypothesis, resulting in fragmented study attempts. In addition, there are now several frameworks for the evaluation and benchmarking of firm performance (FP), but none of these frameworks provide an approach for assessing the competitive advantage of the firm. Therefore, this study aims to explore and determine the dimensionality of items measuring CA construct. The issue has previously been discussed, but there is still no prevalent agreement between scholars as the number of dimensions and items to assess CA should be used. This research investigated the CA measurement items created by past researchers and tailored these items to accommodate the environment of SMEs in Jordan. In this regard, the Delphi technique has been combined by the Structural Equation Modeling (SEM) and also followed the steps of instrument creation developed by Churchill (1979). The primary objective of this research is to develop an instrument capable of assessing CA in Jordanian SME sector. The tool developed in this research provides a relevant and efficient tool that disclosed three aspects by satisfying all the socio-metric properties required by the measuring tool in the social science, namely dimensionality, reliability, and validity.
\end{abstract}

Keywords: Competitive Advantage (CA), Firm Performance (FP), Small and Medium Enterprise (SME), Structural Equation Modelling (SEM), Gross Domestic Product (GDP)

\section{Introduction}

Small businesses can initiate financial progress and rapid industrialization, particularly in emerging nations backed by present scholarly literature (Audretsch, 1998; Urata, Shujiro, and Kawai, 1998; Berry and Mazumder, 1991; Ogechukwu, Ayozie, Oboreh, Umukoro, and Uche, 2013). Most governments around the globe have therefore understood the important commitment that SMEs have produced to the triumph of justifiable development, work development and misery alleviation (Swerczek and Ha, 2003). In addition, most SMEs have been acknowledged as vibrant, creative, effective, and their tiny magnitude enables adaptability, immediate reactions, brief decision-making and policy-making cycle, and faster client reporting (Singh, 2009). Despite the notoriety of SMEs, the output of SMEs has mostly fallen behind aspirations (Arinaitwe, 2006). Therefore, due to international competitiveness, technological growth and changing customer requirements, they are under tremendous stress to withstand in both national and global economies.

In fact, owing to weak investment framework, bad leadership and advertising approach, improper entrepreneurial conduct and other legislative limitations, countless Jordanian SMEs appear to have been shut down within a few years of beginning their operating operations and this is a very prevalent occurrence worldwide (Montoo, 2006). It is therefore becoming increasingly hard for Jordanian small and medium-sized enterprises to endure and thrive in the hostile global enterprise economy (Ahmed, 2001) and Jordan confronting problems in achieving full benefits from the SME industry (Ahmed, 2001; Chowudhury and Rashid, 1996). Competitive advantage (CA) can therefore serve a crucial part in achieving fast economic development due to sustainability of small and medium-sized enterprises and a coherent input to Jordan's GDP. 
The competitive advantage of the company, however, is undeniably a distinctive construct that is at the heart of strategic management literature (Fahy, 2000; Ma, 2000, 2004; Barney, Wright, and Ketchen, 2001; Porter, 1985; Barney, 1991; Peteraf, 1993; Ma, 2004), but there is significant dispute over the construction of the CA and its applicability to the business sector from 1959 to the present (Sachitra, 2016). CA structure is therefore still underdeveloped and ignores a unifying theory, contributing to piecemeal study efforts. In addition, there are now several frameworks for the evaluation and benchmarking of firm performance (FP), but none of these frameworks provide a strategy for assessing the competitive advantage of the firm. As a result, all Jordanian SME industry stakeholders require a measurement tool to assess the CA of SMEs and take the required responsive steps. In his respect, this research aims to investigate and determine the dimensionality of items assessing Jordanian SMEs' CA construct.

\section{Literature Review}

\subsection{Competitive Advantage (CA)}

CA is considered as portion of the upper-level efficiency base (Ismail, Rose, and Abdullah, 2010). CA is defined as the capacity of a company to enhance the value of its products, decrease the cost of its products, or expand business presence or benefit (Grupe and Rose, 2010). Porter (1990) describes profitable benefit at company stage as efficiency development expressed in either reduced expenses or distinguished pricing items. Smith (2013) points out that the competitive advantage is the level to which companies can contend with companies elsewhere in a particular region. Newbert (2008) describes CA as the degree to which a firm investigates its possibilities, risks are neutralized and price reduced.

However, Sigalas (2013) argues that a firm's degree of competitiveness is to explore possibilities, neutralize treatments, and reduce costs. On the other side, according to Ma (1999b) CA is the basis of stronger results that emerges from the differential between companies alongside any dimension of the features and qualities of the company that allows one company to produce strong client valuation than others. According to a company's Flynn, Schroeder and Sakakibara (1995) CA is the manner it generates significance for its clients, enabling it to create and maintain a defensible place in its product market.

It is cleared from CA's prior research that CA comprises of three features (Meutia and Ismail, 2012) namely: Long life, hard to imitate and hard to define. Consequently, CA over rivals is achieved by providing superior value as well as keeping a healthy connection with clients either through reduced rates or by differentiating products and facilities at a fair cost to ensure better performance. As a result, CA is often a key element for a company that provides a company an advantage beyond what the competition has or does.

\subsection{Dimensions and Measurements of Competitive Advantage}

Kadocsa (2006) emphasizes that it is possible to quantify and access the measuring points of competitiveness such as revenue, profit and productivity, but the maximum times are difficult to quantify or access. In addition, Singh, Kiran and Goyal (2015) state that partial productivity indices are not adequately successful in measuring CA and a company's technical progress since there is no universally accepted criterion for measuring productivity. A long-term rather than short-term direction should be taken into consideration by any assessment measure of the competitiveness of a firm. The notion of profitability can be vague as it involves the definition of an era of moment during which the tests are conducted. Profitability can therefore be referred to in the short or long term (Depperu and Cerrato, 2005). These problems contribute to indices being investigated to evaluate competitive advantage rather than efficiency (Vooulgaris, Papadogoonas, and Lemoonakis 2013).

Therefore, there should be definite measurements to assess a company's competitive advantage in attempt to define the variables influencing competitive advantage. Competitive advantage in previous research deals with the value and quality dimension that could be mentioned as cost-based, product-based, and service-based (Ismail, Rose, and Abdullah, 2010). The cost-based benefit includes reduced manufacturing costs and reduced price products. Higher product quality, packaging, layout, and style are the product-based advantages. Through product flexibility, accessibility, shipping velocity, and technical support, business firms can also gain service-based advantages.

This research has created three dimensions to evaluate competitive advantage constructs, namely cost leadership, product quality, and product differentiation, taking into account previous research. These three dimensions are consistent with the cost-based, product-based, and service-based models that are also used in Awwad's (2011) research; Jie, Parton, and Cox (2013); Sukati, Hamid, Baharun, Tat, and Said (2011); Lakhal (2009); Newbert (2008) to evaluate competitive advantage in distinct contexts at firm stage. Furthermore, a single explanatory element is not an appropriate measure of competitiveness, according to Depperu and Cerrato (2005). 


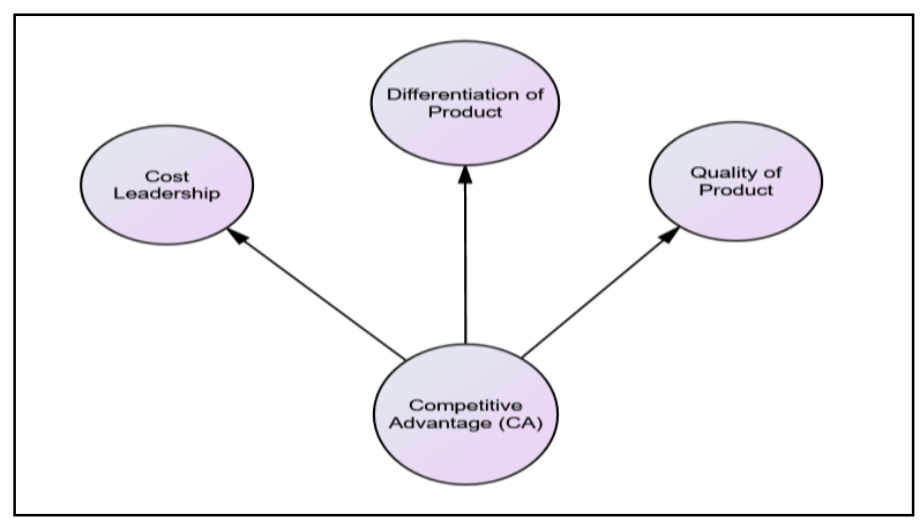

Figure 1. Dimensions of Competitive Advantage (CA)

\subsection{Cost Leadership}

Cost management is a strategy that stresses the efficiency of the organization. Cost leadership's objective is to be the industry's lowest-cost producer of products and facilities (Porter, 1996). Porter (1985) described cost leadership in combination with active marketing as normal trading products. He also stated that cost leadership is expected by decreasing and managing expenses as a means of achieving viable commercial benefit (Porter, 1985).

Therefore, small and medium-sized enterprises are attempting to do company with the stress of minimizing product or service expenses to generate competitive advantage. If the expected sale price can be at least near to the business median, then highest revenue will be earned by the smallest cost manufacturer. This is usually associated with extensive enterprises providing standard products at minimum price and with tiny differentiation that satisfies the total amount of clients, leading in competitive advantage being created. Especially if a company has a significant price benefit over the rivalry and can further increase its market share by doing so (Barney, 1991).

\subsection{Differentiation of Product}

Differentiation relates to differentiating the firm's item or service from its competitor or doing something to be distinctive in the SME industry in an inimitable manner. Differentiation can be accomplished in different respects, such as architecture, brand image, technology, characteristics, customer service, and network of dealers. Product dimension differentiation is usually associated with setting the highest cost for the manufactured goods and providing the customer with additional quality characteristics (Porter, 1996). According to Barney (1991), distinction indicates a suitable cost that includes the additional cost of manufacturing and also gives clients definite grounds for choosing products for consumption over other less distinguished products.

There are many methods in which firms can distinguish themselves and their products or facilities from their competing firms (Thompson \& Strickland, 2008; Porter, 1980). The instances listed above are not just how firms differ from their peers in differentiating their products or facilities. Indeed, Barney and Hesterley (2006) argue that product differentiation is eventually a manifestation of people and organizations ' innovation within firms. It is restricted only by the possibilities that occur or can be generated in a specific sector and by firms' desire and capacity to find methods to bring benefit of those chances creatively (Barney and Hesterley, 2006).

\subsection{Quality of Product}

According to Garvin (1984, 1988); Pirsig (1974); Reeves and Bednar (1994) Product Quality defined the features of an item or service that can add to the satisfaction of specified or presumed client requirements and seeks to create competitive advantage for a business organization as well. Product quality relates to the point to which products fulfill client requirements and stated that improving product quality should result in customer satisfaction and greater revenues (Smith and Wright, 2004).

Shank and Govindarajan (1994) asserted that in order to gain competitive advantage, performance is commonly acknowledged as a main profitable weapon of companies. It has also been argued that performance is the foundation for creating and retaining a worldwide strategic benefit (e.g. Porter 1991; Flynn et al. 1995; Terziovski et al. 1999). Previous surveys by both utility suppliers and merchandise manufacturers have assured that performance appears to boost yields (Bharadwaji and Menoon, 1993; Buzzeell and Galee, 1987; Hendriicks and Siinghal, 1996; Kuzmaa and 
Shankliin, 1992; Poweill, 1995) that create automatic competitive advantage. In this sense, the advantage of generating quality products or services and attaining competitive advantage is that during both excellent and poor financial times a firm can perform well in relation to its competitors.

\section{Method}

The main aim of this study is to develop an instrument capable of measuring CA of a firm as well as to identify relevant dimensions and dimension related items of CA. To be able to fulfill aims, this research usually pursued the rules and stages described in the literature on instrument development (DeVellis, 2003; HinKin, 1995). Thus, the multi-phase protocol of Churchill (1979) and DeVellis (2003) accompanied the development of a multivariate measuring instrument for the construction of Competitive Advantage (CA) as well as the rules of Gerbing \& Anderson (1988) for measuring reliability.

As Jordan faces problems in achieving peak benefits from the SME industry as well as contributing inadequately to domestic GDP, competitive advantage (CA) can serve a crucial part in achieving fast economic development due to sustainability of SMEs and a continuous input to Jordan's GDP. CA structure, however, is still underdeveloped and ignores a unifying hypothesis, resulting in fragmented study attempts. In addition, there are now several frameworks for the evaluation and benchmarking of company results (FP), but none of these frameworks provide a strategy for assessing the competitive advantage of the firm. Researchers therefore conducted this study in the different department of Jordan to create the SME industry CA measuring instrument in Jordan. Researchers drew into account and engaged officials of the various SME industry in Jordan in the stages of the study method.

\subsection{Preliminary Study}

This study's scientists collaborated rigorously to generate operational definitions for the three CA sub-constructs during the first stage of instrument design process, relying heavily on the CA concept provided by Porter (1990), Barney (1991), Ma (1999), Smith (2013), Sigalas (2013), Newbert (2008), and Flynn, Schroeder and Sakakakibara (1995) as well as SME-related literature. Once the scientists decided on conceptual concepts, with a sum of 14 pieces produced, each individually produced objects for all three dimensions. For consistency of significance, the scientists sophisticated object wording to assist guarantee that each object marked no more than one dimension, reaching consensus on each object through the view of the specialists. The ensuing three measurements are all facets of a firm's CA that support face validity.

\subsection{Focus Group Discussion}

Based on the literature of previous leadership, it is difficult to achieve that the maintained indices are most important to the CA framework. First, because the literature reviewed is not linked solely to the SME's CA. Second, because some appropriate factors may not be identified in the literature, the scientists therefore chose to mix deductive and inductive methods to literature assessment (HinKin, 1998). Researchers therefore organized two focus group sessions to check the relevance and completeness of the CA dimensions selected items. According to Cowton \& Downs (2015), the frequent use of concentrate organizations in cultural humanities is a significant qualitative study technique for measuring device growth (Cowton \& Downs, 2015).

In this study, scientists in the first study team meeting and second meeting are intended to deepen the debate on the general CA of distinct SMEs; they regarded the perspective of power engaged in managing SMEs in Jordan. Establishing two focus groups debate comprising 14 main topics with distinct context scientists will obtain the chance to obtain understanding into the distinct views of SME CA measurement. In particular, scientists are trying to find out from the respondents whether the three CA sub-constructs' measurement 12 items chosen in phase 1 are suitable for evaluating a firm's CA or whether there are lacking objects or indices. Three (3) more indicators were introduced as a consequence of the focus groups debate, leading in 15 items chosen and accepted in the tool development stage debate focus group.

\subsection{Delphi Panel \& Pretest}

Focus groups are generally not private and possibly less open-minded (Cowton \& Downs, 2015; Bruggen, E. \& Willems, P. 2009). To solve these disadvantages of focus group debate, this study's scientists used the Delphi technique to achieve consensus on sizes \& objects as well as perform pre-testing to minimize the confusion between items. According to Caffey et al., (2001), Worrell et al. (2013) the Delphi method includes an organized and iterative method in which specialists express their private views in successive sessions.

Specifically, this Delphi board involves ten (10) panelists with distinct professions: (a) owners of SME business and (b) Entrepreneurship and Innovation professionals (scholars, public representatives) with an intense focus on CA. 
The scientists seek agreement within the expert committee by arranging their views after each round (Schmidt, 1997; Rowe et al., 2005; and Von Der Gracht, 2012).

The agreement needed was reached after two stages which led in 5 items being excluded and 10 items being selected. Table 1 provides an outline of products that have been deleted and approved. As pre-testing is critical and is frequently suggested by academics to define issues that are probable to be found from object discrimination, internal consistency, reaction levels, and overall parameter assessment (Hoque \& Awang, 2019; Hoque, Awang, \& Gwadabe, 2018g;Hoque, 2018; Hoque, 2018a; Hoque, 2018b; Hoque et al., 2017; Hoque, Awang, \& Salam, 2017a; Hoque, Awanf, \& Siddiqui, 2017b; Hoque \& Awang, 2016a; Hoque \& Awang, 2016b; Hoque \& Awang, 2016c; Hoque, Awang, \& Ghani, 2016; Awang, 2015). For the prevention of evaluating the performance of the freshly established instrument, 20 respondents were chosen in the pre-test as suggested by Hertzog (2008) with expertise in questionnaire production and customization. The instrument was therefore created and used depending on the specialists ' recommendations.

Table 1. Operational definitions and items of the three dimensions of CA of a firm

\begin{tabular}{|c|c|c|c|c|c|}
\hline $\begin{array}{l}\text { CA } \\
\text { Dimensio } \\
\text { ns }\end{array}$ & Sources & Operational Definition & \& Items of the five dimensions of CA & $\begin{array}{l}\text { Accordi } \\
\text { ng to } \\
\text { Focus } \\
\text { Groups } \\
\end{array}$ & $\begin{array}{l}\text { Accordin } \\
\text { g to } \\
\text { Delphi } \\
\text { Panel } \\
\end{array}$ \\
\hline \multirow{5}{*}{$\begin{array}{l}\text { Cost } \\
\text { Leadershi } \\
\text { p }\end{array}$} & \multirow{5}{*}{$\begin{array}{l}\text { Miller } \\
\text { (1986); } \\
\text { Miller and } \\
\text { Friesen } \\
\text { (1986); } \\
\text { Porter } \\
\text { (1985); } \\
\text { White } \\
\text { (1986); } \\
\text { Yamin et } \\
\text { al. (1999) }\end{array}$} & \multirow{5}{*}{ 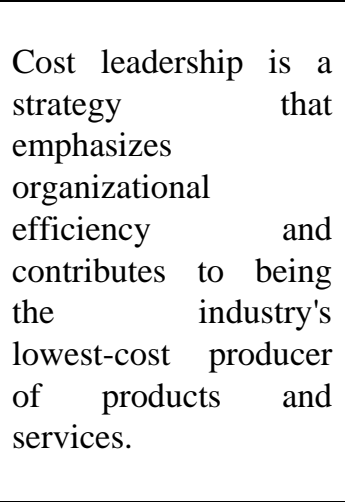 } & $\begin{array}{l}\text { We are happy with the connection } \\
\text { between supplier and vendor in price } \\
\text { monitoring. }\end{array}$ & $\sqrt{ }$ & $\sqrt{ }$ \\
\hline & & & $\begin{array}{l}\text { We are happy with the raw material } \\
\text { inventory turnover. }\end{array}$ & $\sqrt{ }$ & $\sqrt{ }$ \\
\hline & & & $\begin{array}{l}\text { We are attempting to continually } \\
\text { improve surveyor abilities. }\end{array}$ & $\sqrt{ }$ & \\
\hline & & & $\begin{array}{l}\text { To improve effectiveness, we are } \\
\text { using electronic technologies. }\end{array}$ & $\sqrt{ }$ & \\
\hline & & & $\begin{array}{l}\text { We are happy with the efficacy of } \\
\text { main value chain elements. }\end{array}$ & $\sqrt{ }$ & $\sqrt{ }$ \\
\hline \multirow{6}{*}{$\begin{array}{l}\text { Differenti } \\
\text { ation of } \\
\text { Product }\end{array}$} & \multirow{6}{*}{$\begin{array}{l}\text { Miller } \\
\text { (1986); } \\
\text { Miller and } \\
\text { Friesen } \\
\text { (1986); } \\
\text { Porter } \\
\text { (1985); } \\
\text { White } \\
\text { (1986); } \\
\text { Yamin et } \\
\text { al. (1999) }\end{array}$} & \multirow{6}{*}{$\begin{array}{l}\text { Product differentiation } \\
\text { relates to } \\
\text { differentiating its } \\
\text { product or service } \\
\text { from its competitor or } \\
\text { doing something to be } \\
\text { distinctive in an } \\
\text { inimitable manner. }\end{array}$} & $\begin{array}{l}\text { For our product, we use distinctive } \\
\text { technology. }\end{array}$ & $\sqrt{ }$ & \\
\hline & & & $\begin{array}{l}\text { It's hard for rivals to duplicate our } \\
\text { products. }\end{array}$ & $\sqrt{ }$ & $\sqrt{ }$ \\
\hline & & & $\begin{array}{l}\text { The image of our product is } \\
\text { distinctive. }\end{array}$ & $\sqrt{ }$ & $\sqrt{ }$ \\
\hline & & & $\begin{array}{l}\text { We are distinctive in design in } \\
\text { product models. }\end{array}$ & $\sqrt{ }$ & $\sqrt{ }$ \\
\hline & & & In the product mix, we are versatile. & $\sqrt{ }$ & $\sqrt{ }$ \\
\hline & & & $\begin{array}{l}\text { We use innovative marketing strategy } \\
\text { for the item. }\end{array}$ & $\sqrt{ }$ & \\
\hline \multirow{4}{*}{$\begin{array}{l}\text { Quality of } \\
\text { Product }\end{array}$} & \multirow{4}{*}{$\begin{array}{l}\text { Flynn et } \\
\text { al. (1994) }\end{array}$} & \multirow{4}{*}{$\begin{array}{l}\text { The quality of the } \\
\text { product relates to the } \\
\text { point to which } \\
\text { products }\end{array}$} & $\begin{array}{l}\text { Before the item is manufactured, new } \\
\text { item designs are carefully evaluated. }\end{array}$ & $\sqrt{ }$ & \\
\hline & & & $\begin{array}{l}\text { In the new product development } \\
\text { method, customer demands are } \\
\text { carefully evaluated. }\end{array}$ & $\sqrt{ }$ & $\sqrt{ }$ \\
\hline & & & $\begin{array}{l}\text { New product quality is more } \\
\text { important than cutting costs of it. }\end{array}$ & $\sqrt{ }$ & $\sqrt{ }$ \\
\hline & & & $\begin{array}{l}\text { Product quality is more crucial than } \\
\text { timely shipment of product. }\end{array}$ & $\sqrt{ }$ & $\sqrt{ }$ \\
\hline
\end{tabular}




\subsection{Survey Instrument Development and Administration}

The research used 10 chosen items at this point to develop a firm's CA tool. The created products and the tool will be used to evaluate a firm's CA in the pilot research phase. In view of the intent of creating a measuring tool appropriate for a wide spectrum of SMEs in Jordan, the newly developed survey tool was circulated to 220 SME owners in Jordan through postal mail service for pilot study. To understand the research instrument clearly, this study pursued the guidelines suggested by Maxwell (1996); Hoque et al. (2017a) and Hoque et al. (2017b) for the respondents.

A sum of 134 managers finished the survey after a span of eight months, providing a response rate of 60.9 percent, and after removing incomplete survey tools, our pilot study findings are based on responses from 100 managers of SMEs. The organization age ranges between 2 and 12 years in our sample. The employees range from 1 to 250 with an average of 7 employees. A sum of 72 percent of organizations with fewer than 50 staff are small organizations.

\subsection{Pilot Study}

A pilot survey was performed and Exploratory Factor Analysis (EFA) was performed via randomly chosen one hundred (100) participants as a minimum sample size of the pilot research suggested by Hoque et al. (2017), Hoque and Awang (2016), Awang (2015); Hair et al. (2010) to establish the underlying dimensionality of CA construct and determine internal validity. The target population was absolutely considered the recommendations proposed by Salkind (2010) when administering the pilot study instrument.

\subsection{Exploratory Factor Analysis (EFA)}

In this research, EFA used to examine the interrelationships between the three dimensions of CA that found groups of products with sufficient normal variety to warrant their classification as a factor grouping together. Under EFA, Kiser-Meyer-Olkin and Bartlett's sphericity sample were exploited in this research to assess the sampling adequacy suggested for the assessment to face the situation to the variable proportion. For the factor analysis to be appropriate, Bartlett's sphericity test should be significant at $\mathrm{P}<0.05$ (Hair, Black, Rabin \& Anderson, 2010; Hoque et al., 2017; Hoque and Awang, 2016; Awang, 2012 and 2015).

The KMO varies from 0 to 1, but over 0.6 is usually appropriate (Hoque and Awang, 2016; Awang, 2012). Total variance explained before further assessment was also examined as a method of extraction of items in which individual values reaching 1.0 are obtained into different parts (Hoque and Awang, 2016; Awang, 2012; Pallant 2007). In addition, the inverted element matrix was examined and for further evaluation only objects with a factor load above 0.6 were maintained (Hoque and Awang, 2016; Hoque, Awang, Baharu, Siddiqui, 2018a; Hoque, Awang, Jusoff, Salleh, \& Muda, 2017c; Hoque, Awang, Muda, \& Salleh, 2018b; Hoque, Awang, Siddiqui, \& Sabiu, 2018c; Awang, 2012).

Nevertheless, reliability analysis for the test products were performed during the EFA phase and only items with a Cronbach's Alpha of 0.7 and above were considered Hoque, Siddiqui, Awang (2018d); Hoque, Gwadabe, \& Rahman (2017c); Hoque and Awang, (2016); Awang, (2012); Awang et al., (2017a); Fornell and Larcker (1981); Nunnally $(1997,1978)$ and Hair (1998) proposed that a Cronbach's Alpha of 0.70 or greater would reveal that the tool had a higher reliability standard.

\section{Results of Pilot Study}

The result of the pilot study is presented as follows:

Table 2. KMO and Bartlett's test for the items of CA construct

\begin{tabular}{lll}
\hline Kaiser-Meyer-Olkin Measure of Sampling Adequacy. & .848 \\
\hline \multirow{3}{*}{ Bartlett's Test of Sphericity } & Approx. Chi-Square & 667.913 \\
\cline { 2 - 3 } & $\mathrm{df}$ & 45 \\
\cline { 2 - 3 } & Sig. & .000 \\
\hline
\end{tabular}

Table 2 shows an excellent KMO value of 0.848 as it reaches the suggested value of 0.6 (Hoque and Awang, 2016; Awang 2012). In addition, Bartlett's Test's significance value in Table 2 is 0.000 , which is less than 0.05 in meeting the required significance value (Hoque, Siddiqui, Awang, 2018e; Hoque, Siddiqui, Awang,\& Baharu, 2018f; Hoque 
and Awang, 2016; Awang, 2012). Therefore, the KMO valuation near 1.0 and the Bartlett's test significance near to 0.0 indicate that data is adequate and suitable to continue the reduction process (Hoque and Awang, 2016).

Table 3. Total variance explained for CA construct

\begin{tabular}{|c|c|c|c|c|c|c|c|c|c|}
\hline \multirow[t]{2}{*}{$\begin{array}{l}\text { Componen } \\
\mathrm{t}\end{array}$} & \multicolumn{3}{|c|}{ Initial Eigenvalues } & \multirow{2}{*}{$\begin{array}{l}\text { Extraction } \\
\text { Loadings } \\
\text { Total }\end{array}$} & \multirow{2}{*}{\multicolumn{2}{|c|}{$\begin{array}{l}\text { Sums of Squared } \\
\% \text { of Cumulativ } \\
\text { Variance e } \%\end{array}$}} & $\begin{array}{l}\text { Rotation } \\
\text { Loadings }\end{array}$ & \multicolumn{2}{|c|}{ Sums of Squared } \\
\hline & Total & $\begin{array}{l}\% \text { of } \\
\text { Variance }\end{array}$ & $\begin{array}{l}\text { Cumulat } \\
\text { ive } \%\end{array}$ & & & & Total & $\begin{array}{l}\% \text { of } \\
\text { Variance }\end{array}$ & $\begin{array}{l}\text { Cumulativ } \\
\text { e } \%\end{array}$ \\
\hline 1 & 5.231 & 52.310 & 52.310 & 5.231 & 52.310 & 52.310 & 3.089 & 30.887 & 30.887 \\
\hline 2 & 1.726 & 17.255 & 69.565 & 1.726 & 17.255 & 69.565 & 2.522 & 25.220 & 56.107 \\
\hline 3 & 1.077 & 10.775 & 80.340 & 1.077 & 10.775 & 80.340 & 2.423 & 24.233 & 80.340 \\
\hline 4 & .454 & 4.535 & 84.875 & & & & & & \\
\hline 5 & .380 & 3.797 & 88.672 & & & & & & \\
\hline 6 & .300 & 2.996 & 91.669 & & & & & & \\
\hline 7 & .263 & 2.628 & 94.297 & & & & & & \\
\hline 8 & .227 & 2.269 & 96.565 & & & & & & \\
\hline 9 & .189 & 1.889 & 98.455 & & & & & & \\
\hline 10 & .155 & 1.545 & 100.000 & & & & & & \\
\hline
\end{tabular}

Extraction Method: Principal Component Analysis.

The output shows that the EFA obtained three CA construction parts as they exceed the suggested quality of 1 or more (Hoque and Awang, 2016; Awang, 2012) as shown in Table 3. Component 1's Eigenvalue is 5.231, component number 2's Eigenvalue is 1.726, and component number 3's Eigenvalue is 1.077. This shows that the construct is divided into three components for further evaluation (Hoque and Awang, 2016). The above table also indicates a total variance explained is 80.340 percent.

Table 4. Rotated component matrix of CA construct

\begin{tabular}{llll}
\hline \multirow{2}{*}{ Item Code } & \multicolumn{2}{l}{ Components } & 3 \\
\cline { 2 - 3 } & 1 & 2 & \\
\hline DP1 & .859 & & \\
\hline DP2 & .887 & & \\
\hline DP3 & .756 & .853 & \\
\hline DP4 & .862 & .840 & .878 \\
\hline CL1 & & .867 & .811 \\
\hline CL2 & & .802 \\
\hline CL3 & & \\
\hline QP1 & & \\
\hline QP2 & & \\
\hline QP3 & & & \\
\hline
\end{tabular}

Extraction Method: Principal Component Analysis.

Rotation Method: Varimax with Kaiser Normalization. 
Table 4 demonstrates that three dimensions or components have been obtained from the EFA method and all 10 items will be maintained for further research with a factor loading value is 0.6 or higher (Salam \& Hoque, 2019; Hoque et al., 2017a; Hoque et al., 2017b; Afthanorhan et al., 2017; Hoque and Awang, 2016a; Hoque and Awang, 2016b; Awang, 2015a). Therefore, under three dimensions of CA construct 10 items will be considered for further analysis.

\subsection{Reliability Analysis for the Measuring Items}

The Cronbach's Alpha value is exercised in this research to calulate the reliability of the items. Therefore, Kerlinger and Lee (2000) proposed that for valid internal reliability, the Cronbach's Alpha value should be 0.5 or more. Hoque et al. (2017) Hoque and Awang (2016); Awang (2012); Hair (1998); and Nunnally (1997, 1978) proposed that Cronbach's Alpha of 0.6 or greater ensure a reliable measure of internal consistency, while a result of 0.70 specified that the tool had a high standard of quality regarded in this research.

Table 5. Reliability statistics for the seven component of EM construct

\begin{tabular}{lll}
\hline Component & Number of items & Cronbach's Alpha \\
\hline Component 1 & 4 & 0.916 \\
\hline Component 2 & 3 & 0.927 \\
\hline Component 3 & 3 & 0.934 \\
\hline
\end{tabular}

As shown in Table 5, CA construct has a maximum of 10 items. However, component one has 4 items, component two has 3 items, and component three has 3 items. For each component, the Cronbach's Alpha is calculated and has a high reliability standard for component 1 , component 2 , and component 3 as $0.916,0.927$, and 0.934 respectively. Consequently, the findings indicate that all reliability measures for CA's three components exceeded the necessary and suggested amount of 0.7 or more (Salam \& Hoque, 2019; Hoque et al., 2017; Hoque and Awang, 2016a; Hoque and Awang, 2016b; Awang, 2012; Hair, 1998; and Nunnally, 1997; 1978).

As a result, the extracted component with their respective items as shown in Table 5 are reliable and appropriate to measure the CA construct. Therefore, the study could employ those items for data collection in the field study.

\subsection{Main Study Method: Final Validation of the CA Instrument}

The main study's aim was to show the ultimate construct validity and nomological validity of a construct. Convergent validity, construct validity as well as composite reliability have been verified using SEM that also guarantees nomological validity of the CA structure.

\subsection{Sample and Data Collection for Main Study}

The final version of the survey tool was circulated through the postal mail system to the owners of 719 SMEs in Jordan for this academic research. A sum of 396 participants replied to the survey questionnaire after eight months, providing a response rate of 55.08 percent, and after removing unfinished studies, 384 completed responses were obtained from owners of various SMEs in Jordan that were used in the main research assessment.

\section{Results of the Main Study}

Respondents consisted of $67 \%$ male and $33 \%$ female in this study. Their average age was 35 years and for a median of 5 years the companies were in service. $69 \%$ of firms had ten or fewer permanent employees and $19 \%$ had no other employees than themselves and almost $57 \%$ had a university degree. 


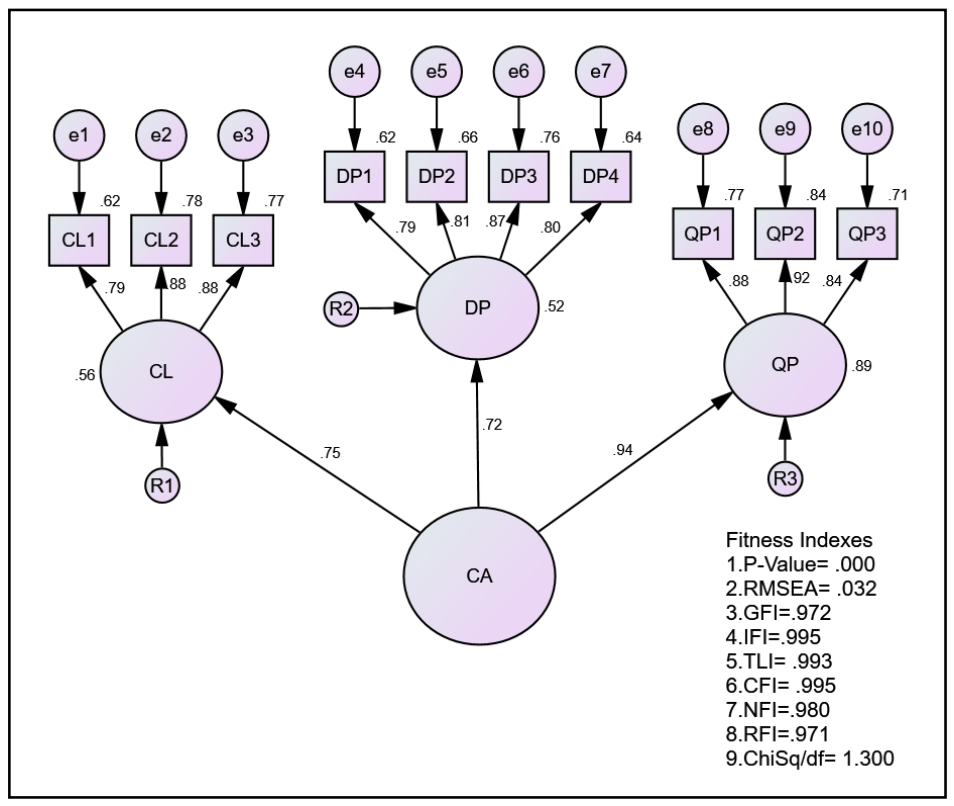

Figure 2. Competitive advantage measurement items and components factor loading in SEM

Table 6. Items description, internal reliability, composite reliability and convergent validity

\begin{tabular}{|c|c|c|c|c|c|}
\hline $\begin{array}{l}\text { Construct } \\
\text { Dimensions }\end{array}$ & $\begin{array}{l}\text { Dimensions } \\
\text { \& Items }\end{array}$ & $\begin{array}{l}\text { Item Factor } \\
\text { Loading }\end{array}$ & $\begin{array}{l}\text { Cronbach's } \\
\text { Alpha }\end{array}$ & $\begin{array}{l}\text { Composite } \\
\text { Reliability (CR) } \\
\text { (above 0.6) }\end{array}$ & $\begin{array}{l}\text { Average } \text { Variance } \\
\text { Extracted }(\mathrm{AVE}) \\
(\text { above } 0.5)\end{array}$ \\
\hline \multirow{3}{*}{$\begin{array}{l}\text { Competitive } \\
\text { Advantage } \\
\text { (CA) }\end{array}$} & CL & .75 & \multirow{3}{*}{.929} & \multirow{3}{*}{.849} & \multirow{3}{*}{.655} \\
\hline & DP & .72 & & & \\
\hline & QP & .94 & & & \\
\hline \multirow{4}{*}{$\begin{array}{l}\text { Differentiation of } \\
\text { Product (DP) }\end{array}$} & DP1 & .79 & \multirow{4}{*}{.917} & \multirow{4}{*}{.890} & \multirow{4}{*}{669} \\
\hline & DP2 & .81 & & & \\
\hline & DP3 & .87 & & & \\
\hline & DP4 & .80 & & & \\
\hline \multirow{3}{*}{$\begin{array}{l}\text { Cost } \\
\text { Leadership (CL) }\end{array}$} & CL1 & .79 & \multirow{3}{*}{.918} & \multirow{3}{*}{.887} & \multirow{3}{*}{.724} \\
\hline & CL2 & .88 & & & \\
\hline & CL3 & .88 & & & \\
\hline \multirow{3}{*}{$\begin{array}{l}\text { Quality of } \\
\text { Product (QP) }\end{array}$} & QP1 & .88 & \multirow{3}{*}{.872} & \multirow{3}{*}{.912} & \multirow{3}{*}{.775} \\
\hline & QP2 & .92 & & & \\
\hline & QP3 & .84 & & & \\
\hline
\end{tabular}

Factor charging scores for all three-dimensional products consisting of competitive advantage structure together with Cronbach Alpha, CR and AVE for each dimension of the CA structure as shown in Table 6 indicating latent construction (i.e. CA) have reached the necessary amount for Unidimensionality; Convergent Validity, Internal Reliability, and Construct Reliability. Nomological validity was determined by checking the structural model after establishing the construct's validity and reliability. P-value=0.00; RMSEA=.032; GFI=.972; IFI=.995; CFI=.995; $\mathrm{TLI}=.993 ; \mathrm{NFI}=.980 ; \mathrm{RFI}=.971 ; \mathrm{ChiSq} / \mathrm{df}=1.300)$. In the model, there were statistically significant $(\mathrm{p}<.001)$ positive paths in each path and Path coefficients (i.e. $\beta$ ) scores varied from .749 to .936 , supporting the nomological value of the CA scale. 


\section{Conclusion}

This research verified the fresh CA instrument's accuracy and legitimacy. Validity of the construct was verified through the achievement of fitness indexes. Nomological value was verified using government sample information to evaluate an SEM system consisting of variable background and result. As stated, we discovered important beneficial interactions between the preceding, competitive benefit, and factors of effects that support the nomological validity of the fresh CA scale. With a domestic sample of SMEs ' market benefit in Jordan, the same procedures for analyzing reliability and construct validity were conducted and verified.

This study confirmed the reliability and validity of the new CA instrument. Validity of the construction was verified through the accomplishment of fitness indexes. Nomological value was verified using government sample data to evaluate an SEM model consisting of variable perspective and consequence. As stated, we discovered important beneficial interactions between the preceding, competitive benefit, and factors of effects that support the nomological validity of the new CA scale. With a national sample of SMEs ' competitive advantage in Jordan, the same procedures for testing reliability and construct validity were conducted and verified. With a national sample of SMEs' competitive advantage in Jordan, the same procedures for testing reliability and construct validity were conducted and verified.

The nomological validity of the CA scale has been verified; all statistically significant values of the SEM design route $(\mathrm{p}<.001)$. Based on previous appropriate literature, this research attempted and effectively developed the Competitive Advantage Dimensions (i.e. Product Differentiation, Cost Leadership, and Product Quality). In addition, it is also evident that $\mathrm{CA}$ is a multi-dimensional building. The current study therefore adds to the development of CA studies, especially in the framework of SMEs.

The current research also assured that the latest CA tool is internally coherent, multi-dimensional, and sample-wide robust by requiring instrument creation and validation processes. Thus, the present competitive advantage (CA) measuring tool will assist potential scientists conduct further studies on the notion of SME business and also assist minimize the study gap of quantitative analysis on the idea of competitive advantage.

\section{References}

Ahmed, M. U. (2001). Globalization and competitiveness of Bangladeshi Small Scale Industries (SSIs): An analysis of the prospects and challenges, p. 2. CPD/UPL published, Bangladesh facing the Challenges of Globalization, IRDB.

Alipour, M., \& Mohammadi, M. H. (2011). The Effect of Customer Relationship Management (CRM) On Achieving Competitive Advantage of Manufacturing Tractor. Global Journal of Management and Business Research, 11(5), 26-35.

Anton, G. (2000). A Study of Competitive Advantage Services. In C. A. Brebbia (Ed.), Management Information Systems. Retrieved from www.witpress.com

Arinaitwe, S. K. (2006). SME and its evaluation. Journal of American Academy of Business, 1(2), 167-178.

Audretsch, D. B. (1998, June). The economic role of Small and Medium - sized Enterprises in United States. Paper presented at the World Bank conference on Small and Medium Enterprises, Washington, DC.

Awang, Z. (2012). Research Methodology and Data Analysis. UiTM Press, UiTM, Malaysia.

Awang, Z. (2015). SEM made simple: A Gentle Approach to Learning Structural Equation Modeling. Bandar Baru Bangi: MPWS Rich Resources.

Awang, Z., Afthanorhan, A., Mohamad, M., \& Asri, M. A. M. (2015a). An evaluation of measurement model for medical tourism research: the confirmatory factor analysis approach. International Journal of Tourism Policy, 6(1), 29-45. https://doi.org/10.1504/IJTP.2015.075141

Awang, Z., Ahmed, U., Hoque, A. S. M. M., Siddiqui, B. A., Dahri, A. S., \& Muda, H. (2017a, October 7-8). The Mediating Role of Meaningful Work in the Relationship Between Career Growth Opportunities and Work Engagement. International Academic Confernce on Business and Economics (IACBE 2017), Faculty of Economics and Management Sciences (FESP), Universiti Sultan Zainal Abidin (UniSZA). https://doi.org/10.6007/IJARBSS/v8-i11/5168

Awwad, A. S. (2011). The influence of tactical flexibilities on the competitive advantage of a firm: An empirical study on Jordanian Industrial Companies. International Journal of Business and Management, 6(1), 45-60. https://doi.org/10.5539/ijbm.v6n1p45 
Babin, B. J., Darden, W. R., \& Griffin, M. (1994). Work and/or fun: measuring hedonic and utilitarian shopping value. Journal of Consumer Research, 20, 644-56. https://doi.org/10.1086/209376

Barney, J. B. (1991). Firm resources and sustained competitive advantage. Journal of Management, 17, 99-120. https://doi.org/10.1177/014920639101700108

Barney, J. B., \& Hesterly, W. S. (2006). Strategic Management and Competitive Advantage: Concepts and Cases. Pearson: Harlow.

Barney, J., Wright, M., \& Ketchen, D. J. (2001). The Resource-Based view of the firm: ten years after 1991. Journal of Management, 27(6), 625-641. https://doi.org/10.1177/014920630102700601

Berry, A., \& Mazumdar, D. (1991). Small-Scale Industry in the Asian-Pacific region. Asian Pacific Economic Literature, 5(2), 35-67. https://doi.org/10.1111/j.1467-8411.1991.tb00048.x

Bharadwaj, S. G., \& Menon, A. (1993). Determinants of success in service industries: A PIMS-based empirical investigation. Journal of Services Marketing, 7(4), 19-40. https://doi.org/10.1108/08876049310047715

Bruggen, E., \& Willems, P. (2009). A critical comparison of offline focus groups, online focus groups and $\mathrm{e}^{-}$delphi. International Journal of Marketing Research, 51, 363-381. https://doi.org/10.1177/147078530905100301

Buzzell, R. D., \& Gale, B. T. (1987). The PIMS Principles: Linking Strategy to Performance. Free Press, New York.

Caffey, R. H., Kazmierczak, R. F., \& Avault, J. W. (2001). Developing consensus indicators of sustainability for southeastern United States aquaculture. Louisiana Agricultural Experiment Station, LSU Agricultural Center: Baton Rouge, LA: USA. https://doi.org/10.2139/ssrn.242312

Callahan, J., \& Lasry, E. (2004). The Importance of Customer Input in the Development of Very New Products, $R \& D$ Management, 34(2), 107-120. https://doi.org/10.1111/j.1467-9310.2004.00327.x

Chowdhury, R., \& Rashid, H. (1996). The role of small scale industries in an under - developed economy with reference to Jordan. Chittagong University Studies (Commerce), 12, 45-48.

Churchill, G. A. Jr. (1979). Paradigm for developing better measures of marketing constructs. Journal of Marketing Research, 16(1), 64-73. https://doi.org/10.1177/002224377901600110

Coltman, T., Devinney, T. M., \& Midgley, D. F. (2011). Customer relationship management and firm performance, Journal of Information Technology, 26(3), 205-219. https://doi.org/10.1057/jit.2010.39

Cowton, C. J., \& Downs, Y. (2015). Use of focus groups in business ethics research: Potential, problems and paths to progress. Bus. Ethics Eur. Rev., 24, 54-66. https://doi.org/10.1111/beer.12097

Crosby, P. B. (1979). Quality is Free. McGraw-Hill, New York.

Curry, A. (2004). Evaluating CRM to contribute to TQM. Marketing Improvement Intelligence \& Planning, 13.

Daniel, S. J., Reitsperger, W. D., \& Gregson, T. (1995). Quality Consciousness in Japanese and U.S. Electronics Manufacturers: An Examination of the Impact of Quality Strategy and Management Control Systems on Perceptions of the Importance of Quality to Expected Management Rewards. Management Accounting Research, 6, 367-382. https://doi.org/10.1006/mare.1995.1026

Dean, E., Hather, J., \& Dane, G. (2008). Customer relationship management strategic application and organizational effectiveness: an empirical investigation. Journal of Strategic Marketing, 17(1), 75-96. https://doi.org/10.1080/09652540802619301

Depperu, D., \& Cerrato, D. (2005). Analyzing international competitiveness at the firm level: Concepts and measures. Quaderni del Dipartimento di Scienze. Retrieved from http://dipartimenti.unicatt.it/diseswp_azzurra_05_32.pdf

DeVellis, R. F. (2003). Scale Development: Theory and Applications. Sage: Thousand Oaks, CA, USA.

Esen, S., \& Uyar, H. (2012). Examining the competitive structure of Turkish tourism industry in comparison with diamond model. Procedia - Social and Behavioral Sciences, 62, 620-627. https://doi.org/10.1016/j.sbspro.2012.09.104

Fahy, J. (2000). The Resource-Based view of the firm: Some stumbling-blocks on the road to understanding sustainable competitive advantage. Journal of European Industrial Training, 24, 94-104. https://doi.org/10.1108/03090590010321061 
Farole, T., Guilherme R. J., \& Wagle, S. (2010). Analyzing trade competitiveness: A diagnostics approach. Policy Research Working Paper No. 5329. The World Bank, Poverty Reduction and Economic Management Network, International Trade Department.

Fischer, C., \& Schornberg, S. (2007). Assessing the competitiveness situation of EU food and drink manufacturing industries: An indexbased approach. Journal of Agribusiness, 23(4), 473-495. https://doi.org/10.1002/agr.20139

Flynn, B. B., Schroeder, R. G., \& Sakakibara, S. (1994). A Framework for Quality Management Research and an Associated Measurement Instrument. Journal of Operations Management, 11(4), 339-366. https://doi.org/10.1016/S0272-6963(97)90004-8

Flynn, B. B., Schroeder, R. G., \& Sakakibara, S. (1995). The Impact of Quality Management Practices on Performance and Competitive Advantage. Decision Sciences, 26(5), 659-691. https://doi.org/10.1111/j.1540-5915.1995.tb01445.x

Fornell, C., \& Larcker, D. F. (1981). Evaluating structural equation models with unobservable variables and measurement error. Journal of Marketing Research, 18(1), 39-50. https://doi.org/10.1177/002224378101800104

Foster, G., \& Sjoblom, L. (1996). Quality Improvement Drivers in the Electronics Industry. Journal of Management Accounting Research, 8, 55-86.

Garvin, D. A. (1984). What does Product Quality really mean?. Sloan Management Review, Fall, 25-43.

Garvin, D. A. (1988). Managing Quality: The Strategic and Competitive Edge. Free Press, New York.

Gerbing, D. W., \& Anderson, J. C. (1988). An updated paradigm for scale development incorporating unidimensionality and its assessment. Journal of Marketing Research, 25(2), 186-192. https://doi.org/10.1177/002224378802500207

Grupe, C., \& Rose, A. (2010). China, India, and the Socioeconomic Determinants of Their Competitiveness. Journal of Economics Research International, 1-15. https://doi.org/10.1155/2010/860425

Hair, J. F. Jr., Anderson, R. E., Tatham, R. L., \& Black, W. C. (1998). Multivariate Data Analysis (5th ed.). Upper Saddle River, NJ: Prentice Hall.

Hair, J. F., Black, W. C., Babin, B. J., \& Anderson, R. E. (2010). Multivariate Data Analysis (7th ed.). Prentice Hall, Upper Saddle River, New Jersey.

Hair, J., Black, B., Babin, B., Anderson, R., \& Tatham, R. (2006). Multivariate Data Analysis (6th ed.). Upper Saddle River, NJ: Prentice-Hall.

Hendricks, K. B., \& Singhal, V. R. (1996). Quality awards and the market value of the firm: An empirical investigation. Management Science, 42(3), 415-436. https://doi.org/10.1287/mnsc.42.3.415

Hertzog, M. A. (2008). Considerations in determining sample size for pilot studies. Research in Nursing \& Health, 31, 180-191. https://doi.org/10.1002/nur.20247

Hinkin, T. R. (1995). A review of scale development practices in the study of organizations. Journal of Management, 21, 967- 988. https://doi.org/10.1177/014920639502100509

Hinkin, T. R. (1998). A brief tutorial on the development of measures for use in survey questionnaires. Organizational Research Method, 1, 104-121. https://doi.org/10.1177/109442819800100106

Hoque, A. S. M. M. (2018). Digital Device Addiction Effect on Lifestyle of Generation Z in Bangladesh. Asian People Journal (APJ), 1(2), 21-44.

Hoque, A. S. M. M. (2018a). The effect of entrepreneurial orientation on Bangladeshi SME performance: Role of organizational culture. International Journal of Data and Network Science, 2(1), 1-14. https://doi.org/10.5267/j.ijdns.2018.7.001

Hoque, A. S. M. M. (2018b). Does government support policy moderate the relationship between entrepreneurial orientation and Bangladeshi SME performance? A SEM approach. International Journal of Business Economics and Management Studies, 6(3), 37-59.

Hoque, A. S. M. M., \& Awang, Z. (2016a). The Sway of Entrepreneurial Marketing on Firm Performance: Case of Small and Medium Enterprises (SMEs) in Bangladesh (pp. 174-194). Terengganu International Business and Economics Conference (TiBEC-V), Terengganu, Universiti Teknologi Mara (UiTM). 
Hoque, A. S. M. M., \& Awang, Z. (2016b). Exploratory Factor Analysis of Entrepreneurial Marketing: Scale Development and Validation in the SME context of Bangladesh (pp. 20-22). International Social Sciences and Tourism Research Conference, Terengganu, UniSZA.

Hoque, A. S. M. M., \& Awang, Z. (2016c, October 8-10). The Impact of Marketing Strategy on Small and Medium Scale Enterprises (SMEs): Case Study in Bangladesh. International Postgraduate Research Conference (IPRC 2016), Universiti Sultan Zainal Abidin (UniSZA), Gong Badak Campus, Kuala Terengganu, Malaysia.

Hoque, A. S. M. M., \& Awang, Z. (2019). Does gender difference play moderating role in the relationship between entrepreneurial marketing and Bangladeshi SME performance?. Accounting, 5(1), 35-52. https://doi.org/10.5267/j.ac.2018.6.001

Hoque, A. S. M. M., Awang, Z., \& Ghani, N. A. (2016, October 6-8). Conceptual Model for Quality of Life in the Perspective of Social Entrepreneurship. International Conference on Science, Engineering, Management and Social Science (ICSEMSS 2016), Universiti Teknologi Malaysia (UTM), Johor Bahru, Malaysia.

Hoque, A. S. M. M., Awang, Z., \& Gwadabe, U. M. (2018g). The Effect of Entrepreneurial Marketing on Bangladeshi SME performance and the Role of Organizational Culture: A Structural Equation Modelling. Journal of Management and Operation Research, 1, 1-21.

Hoque, A. S. M. M., Awang, Z., \& Salam, S. (2017a, September 21-22). The Effects of Relationship Marketing on Firm Performance: Small and Medium Enterprises (SMEs) in Bangladesh. 1st International Conference on Business and Management (ICBM-2017), BRAC Business School (BBS), BRAC University, Dhaka, Bangladesh.

Hoque, A. S. M. M., Awang, Z., \& Siddiqui, B. A. (2017b). Technopreneurial Intention among University Students of Business Courses in Malaysia: A Structural Equation Modeling. International Journal of Entrepreneurship and Small \& Medium Enterprise (IJESME), 4, 1-16.

Hoque, A. S. M. M., Awang, Z., Baharu, S. M. A. T., \& Siddiqui, B. A., (2018a, July). Upshot of Generation 'Z' Entrepreneurs' E-lifestyle on Bangladeshi SME Performance in the Digital Era. International Journal of Entrepreneurship and Small \& Medium Enterprise (IJESME), 5, 97-118.

Hoque, A. S. M. M., Awang, Z., Jusoff, K., Salleh, F., \& Muda, H. (2017c). Social Business Efficiency: Instrument Development and Validation Procedure using Structural Equation Modelling. International Business Management, 11(1), 222-231.

Hoque, A. S. M. M., Awang, Z., Muda, H., \& Salleh, F. (2018b). Ramification of crowdfunding on Bangladeshi entrepreneur's self-efficacy. Accounting, 4(4), 129-138. https://doi.org/10.5267/j.ac.2018.4.001

Hoque, A. S. M. M., Awang, Z., Siddiqui, B. A., \& Sabiu, M.S. (2018c). Role of Employee Engagement on Compensation System and Employee Performance Relationship among Telecommunication Service Providers in Bangladesh. International Journal of Human Resource Studies, 8(3), 19-37. https://doi.org/10.5296/ijhrs.v8i3.13081

Hoque, A. S. M. M., Gwadabe, U. M., \& Rahman, M. A. (2017d). Corporate Entrepreneurship Upshot on Innovation Performance: The Mediation of Employee Engagement. Journal of Humanities, Language, Culture and Business, 1(6), 54-67.

Hoque, A. S. M. M., Siddiqui, B. A., \& Awang, Z. (2018d, July). Technopreneurial Competency Effect on Technology-based SME Performance: A Structural Equation Modelling on Bangladeshi SMEs. International Journal of Entrepreneurship and Small \& Medium Enterprise (IJESME), 5, 55-73.

Hoque, A. S. M. M., Siddiqui, B. A., \& Awang, Z. (2018e). Technopreneurial Competencies Effects on Bangladeshi SME Performance: A Structural Equation Modeling. 2nd ASIA International Multidisciplinary Conference (AIMC 2018), Faculty of Management, Universiti Teknologi Malaysia (UTM), Johor Bahru, Malaysia, May $12-13$.

Hoque, A. S. M. M., Siddiqui, B. A., Awang, Z., \& Baharu, S. M. A. T. (2018f). Exploratory Factor Analysis of Entrepreneurial Orientation in the Context of Bangladeshi Small and Medium Enterprises (SMEs). European Journal of Management and Marketing Studies, 3(2), 81-94.

Ismail, A. I., Rose, R. C., Abdullah, H., \& Uli, J. (2010). The relationship between organizational competitive advantage and performance moderated by the age and size of firms. Asian Academy of Management Journal, $15(2), 157-173$. 
Ismail, A. I., Rose, R. C., Uli, J., \& Abdullah, H. (2012). The relationship between organisational resources, capabilities, systems and competitive advantage. Asian Academy of Management Journal, 17(1), 151-173.

Jamal, A., \& Naser, K. (2002). Customer satisfaction and retail banking: an assessment of some of the key antecedents of customer satisfaction in retail banking. International Journal of Bank Marketing, 20(4), 146-60. https://doi.org/10.1108/02652320210432936

Jie, F., Parton, K. A., \& Cox, R. J. (2013). Linking supply chain practices to competitive advantage. British Food Journal, 115(7), 1003-1024. https://doi.org/10.1108/BFJ-10-2010-0181

Kadocsa, G. (2006). Research of competitiveness factors of SME. Acta Polytechnica Hungarica, 3(4), 71-84.

Kennedy, P. L., Harrison, R. W., Kalaitzandonakes, N. G., Peterson, H. C., \& Rindfuss, R. P. (1997). Perspectives on evaluating competitiveness in agribusiness industries. Agribusiness, 13(4), 385-392. https://doi.org/10.1002/(SICI)1520-6297(199707/08)13:4<385::AID-AGR4>3.0.CO;2-V

Kozena, M., \& Chladek, T. (2012). Company competitiveness measurement depending on its size and field of activities. Journal of Procedia - Social and Behavioral Sciences, 58, 1085-1090. https://doi.org/10.1016/j.sbspro.2012.09.1089

Kurokawa, T., Tembo, F., \& Velde, D. W. (2010). Challenges for the 'one village one product' (OVOP) movement in Sub-Saharan Africa: Insights from Malawi, Japan, and Thailand Report. Landon: Overseas Development Institute.

Kuzma, A. T., \& Shanklin, W. L. (1992). How medium-market-share companies achieve superior profitability. Journal of Consumer Marketing, 9, Winter, 34-49. https://doi.org/10.1108/08858629210035391

Lakhal, L. (2009). Impact of quality on competitive advantage and organizational performance. The Journal of the Operational Research Society, 60(5), 637-664. https://doi.org/10.1057/palgrave.jors.2602601

Latruffe, L. (2010). Competitiveness, productivity and efficiency in the agricultural and agrifood sectors. OECD Food, Agriculture and Fisheries Papers, 30. OECD Publishing.

Levitt, T. (1960). Marketing myopia. Harvard Business Review, 38(3), 45-56. https://doi.org/10.1016/S0007-6813(60)80044-4

Liu, C. L. E., Ghauri, P. N., \& Sinkovics, R. R. (2010). Understanding the impact of relational capital and organizational learning on alliance outcomes. Journal of World Business, 45(3), 237-249. https://doi.org/10.1016/j.jwb.2009.09.005

Ma, H. (1999). Creation and Preemption for Competitive Advantage. Management Decision, 37(3), 259-267. https://doi.org/10.1108/00251749910264497

Ma, H. (2000). Competitive Advantage and Firm Performance. Competitiveness Review, 10(2), 1-16. https://doi.org/10.1108/eb046396

Ma, H. (2004). Toward Global Competitive Advantage. Management Decision, 42(7), 907-924. https://doi.org/10.1108/00251740410550961

Maxwell, J. A. (1996). Qualitative Research Design: An Interactive Approach. Thousand Oaks, CA: Sage.

Meutia, T., \& Ismail, T. (2012). The development of entrepreneurial social competence and business network to improve competitive advantage and business performance of small medium sized enterprises: A case study of batik industry in Indonesia. Journal of Procedia - Social and Behavioral Sciences, 65, 46-51. https://doi.org/10.1016/j.sbspro.2012.11.089

Miller, D. (1986). Configurations of strategy and structure: towards a synthesis. Strategic Management Journal, 7 , 233-249. https://doi.org/10.1002/smj.4250070305

Miller, D., \& Friesen, P. H. (1986). Porter's (1980) generic strategic and performance: an empirical examination with American data. Part 1: testing Porter. Organizational Studies, 7, 37-41. https://doi.org/10.1177/017084068600700103

Montoo, A. A. (2006). SME in Jordan. CACCI Journal, 1, 1-19.

Newbert, S. L. (2008). Value, rareness, competitive advantage, and performance: A conceptual-level empirical investigation of the resource-based view of the firm. Strategic Management Journal, 29, 745-768. https://doi.org/10.1002/smj.686 
Nunnally, J. C. (1978). Psychometric Theory (2nd ed.). New York: McGraw-Hill.

Nunnally, J. C. (1997). Psychometric Theory. New York: McGraw Hill.

Ogechukwu, A. D., Oboreh, J. S., Umukoro, F., \& Uche, V. A. (2013). Small and Medium Scale Enterprises (SMEs) in Nigeria: The Marketing Interface. Global Journal of Management and Business Research: Marketing, 1(9).

Peteraf, M. A. (1993). The cornerstones of competitive advantage: a resource-based view. Strategic Management Journal, 14(3), 179-191. https://doi.org/10.1002/smj.4250140303

Piatkowski, M. (2012). Factors strengthening the competitive position of SME sector enterprises. An example for Poland. Procedia - Social and Behavioral Sciences, 58(2), 69-278. https://doi.org/10.1016/j.sbspro.2012.09.1001

Pirsig, R. M. (1974). Zen and the Art of Motorcycle Maintenance. Bantam Books, New York.

Porter, M. E. (1980). Competitive Strategy: Techniques for Analyzing Industries and Competitors. New York: Free Press.

Porter, M. E. (1985). Competitive Advantage: Creating and Sustaining Superior Performance. New York, NY: The Free Press.

Porter, M. E. (1990). The Competitive Advantage of Nations. New York, NY: The Free Press. https://doi.org/10.1007/978-1-349-11336-1

Porter, M. E. (1991). Towards a dynamic theory of strategy. Strat. Mgmt. J., 12, 95-117. https://doi.org/10.1002/smj.4250121008

Porter, M. E. (1996). Competitive Advantage, Agglomeration Economies, and Regional Policy. International Regional Science Review, 19(1-2), 85-90. https://doi.org/10.1177/016001769601900208

Powell, T. C. (1995). Total quality management as competitive advantage: A review and study. Strategic Management Journal, 16(1), 15-37. https://doi.org/10.1002/smj.4250160105

Powell, T. C. (2001). Competitive advantage: Logical and philosophical considerations. Strategic Management Journal, 22(9), 875-888. https://doi.org/10.1002/smj.173

Reeves, C. A., \& Bednar, D. A. (1994). Defining quality: Alternatives and implications. Academy of Management Review, 19(3), 419-445. https://doi.org/10.5465/amr.1994.9412271805

Rowe, G., Wright, G., \& McColl, A. (2005). Judgment change during Delphi-like procedures: The role of majority influence, expertise, and confidence. Technol Forecast Social Change, 72, 377-399. https://doi.org/10.1016/j.techfore.2004.03.004

Sachitra, V. (2016). Review of Competitive Advantage Measurements: Reference on Agribusiness Sector. Journal of Scientific Research \& Reports, 12(6), 1-11. https://doi.org/10.9734/JSRR/2016/30850

Sachitra, V., \& Chong S. C. (2015). Enhancing competitive advantage of Sri Lankan minor export crops. Journal of Global Economics, Management and Business Research, 4(4), 185-194.

Salam, S., \& Hoque, A. S. M. M. (2019). The Role of Social Media and Effect of Relationship Marketing on Sme Performance in Bangladesh: Multi-Group CFA. Asian People Journal (APJ), 2(1), 12-31.

Salkind, N. J. (2010). Pilot study: Encyclopedia of Research Design (Vol. 2, pp 1032-1033). Thousand Oaks, CA: Sage Publications.

Schmidt, R. C. (1997). Managing delphi surveys using nonparametric statistical techniques. Decision Science, 28 , 763-774. https://doi.org/10.1111/j.1540-5915.1997.tb01330.x

Shank, J., \& Govindarajan, V. (1994). Measuring the Cost of Quality: A Strategic Cost Management Approach. Journal of Cost Management, 8(2), 143-148.

Sigalas, C., \& Pekka Economou, V. (2013). Revisiting the concept of Competitive Advantage: Problems and fallacies arising from its conceptualization. Journal of Strategy and Management, 6(1), 61-80. https://doi.org/10.1108/17554251311296567

Sigalas, C., Economou, V. P., \& Georgopoulos, N. B. (2013). Developing a measure of competitive advantage. Journal of Strategy and Management, 6(4), 320-342. https://doi.org/10.1108/JSMA-03-2013-0015 
Sing, R. (2009). Do your library has a marketing culture? Implications for service providers. Library Management, 30(3), 117-137. https://doi.org/10.1108/01435120910937302

Singh, S., Kiran, R., \& Goyal, D. (2015). Identification of key factors for enhancing competitiveness an exploratory study of the selected agribiotech firms of Punjab in India. Agricultural Economics-Czech, 61, 179-188. https://doi.org/10.17221/26/2014-AGRICECON

Smith, M. (2013). Issues of competitiveness and regional growth in relation to transport infrastructure investment: A literature review on assessment methodology. Retrieved from http://www.i-ceu.eu/deliverables/I-C-EU_WP1_D1.1.pdf

Smith, R. E., \& Wright, W. F. (2004). Determinants of Customer Loyalty and Financial Performance. Journal of Management Accounting Research, 16,183-205. https://doi.org/10.2308/jmar.2004.16.1.183

Sukati, I., Hamid, A. B. A., Baharun, R., Tat, H. H., \& Said, F. (2011). An investigation of the relationship between supply chain management practices and competitive advantage of the firm. Contemporary Marketing Review, l(4), 1-13.

Swierczek, F. W., \& Ha, T. T. (2003). Entrepreneurial orientation, Uncertainty avoidance and Firm Performance: An analysis of Thai and Vietnamese SMEs. International Journal of Entrepreneurship and Innovation, 4(1), 46-58. https://doi.org/10.5367/000000003101299393

Tambunan, T. T. H. (2011). The Impact of the 2008-2009 global economic crises on a developing country. Economy: Studies From Indonesia, 2(3), 75-197.

Terziovski, M., Sohal, A., \& Moss, S. (1999, August). Longitudinal Analysis of Quality Management Practices in Australian Organizations. Total Quality Management, 915-926. https://doi.org/10.1080/0954412997325

Thompson, A. A., \& Strickland, J. (2008). Crafting and executing strategy: The quest for competitive advantage. New York: McGraw-Hill Irwin

Tsukahara, O. (2006). SMEs financing in Japan. Tokyo, Japan Finance Corporation for SMEs (JASME).

Urata, S., \& Kawai, H. (1998, June 11-12). Technological progress by Small and Medium Enterprises in Japan. Paper prepared for the World Bank Workshop on Small and Medium Enterprises.

Von Der Gracht, H. A. (2012). Consensus measurement in Delphi studies: Review and implications for future Quality assurance. Technol Forecast Social Change, 79, 1525-1536. https://doi.org/10.1016/j.techfore.2012.04.013

Voulgaris, F., Papadogonas, P., \& Lemonakis, C. (2013). Drivers of competitiveness in the manufacturing industry: The case of technology sectors in Greece. Journal of Economics and Development Studies, 1(3), 32-40.

White, R. E. (1986). Generic business strategics, organizational context and performance in strategy research: a comparison of approaches. Academy of Management Review, 11(4), 801-814. https://doi.org/10.5465/amr.1986.4283976

Worrell, J. L., Di Gangi, P. M., \& Bush, A. A. (2013). Exploring the use of the Delphi method in accounting information systems research. International Journal of Accounting Information System, 14, 193-208. https://doi.org/10.1016/j.accinf.2012.03.003

Yamin, S., Gunasekaran, A., \& Mavondo, F. T. (1999). Relationship between generic strategies, competitive advantage and organizational performance: an empirical analysis. Technovation, 19, 507-518. https://doi.org/10.1016/S0166-4972(99)00024-3 